PSICOLOGIA,SAÚDE \& DOENÇAS, 2015, 16(2), 174-186

EISSN - 2182-8407

Sociedade Portuguesa de Psicologia da Saúde - SPPS - www.sp-ps.com

DOI: http://dx.doi.org/10.15309/15psd160204

\title{
THE ECONOMIC RECESSION AND MENTAL HEALTH: ANALYSIS OF THE PORTUGUESE SITUATION
}

\author{
João Nuno Ribeiro Viseu ${ }^{1}{ }^{1}$, Saul Neves de Jesus ${ }^{1}$, Rita Leal ${ }^{1}$, Patrícia Valle ${ }^{1}$, Joana Santos ${ }^{1}$ \\ Rafaela Dias Matavelli ${ }^{1}, \&$ Esther Greenglass ${ }^{2}$
}

${ }^{1}$ Research Centre for Spatial and Organizational Dynamics, University of Algarve, Faro, Portugal; ${ }^{2}$ York University, Department of Psychology, Toronto, Canada.

\begin{abstract}
Recently, some European countries (e.g., Greece, Ireland, and Portugal) suffered an economic recession, mainly due to problems in the banking system and high sovereign debt. Economic stressors, such as economic hardship, financial threat, and financial well-being may contribute negatively to individuals' psychological health, potentiating the appearance of negative psychological outcomes. The objective of the current research was to analyze the impact of economic stressors (i.e., economic hardship, financial threat, and financial well-being) on mental health indicators (i.e., stress, anxiety, and depression). Data from a sample of 729 Portuguese participants was collected, 482 (66.1\%) women and 247 (33.9\%) men, with an average age of, approximately, 37 years old $(M=36.99 ; S D=12.81)$. Structural Equation Modeling (SEM) was used to examine the relationship between the economic stress and psychological health variables. The obtained results demonstrated a model with economic hardship and financial threat as significant predictors of stress, anxiety, and depression, while financial well-being was a significant predictor of anxiety and depression. Some implications of these results are discussed.
\end{abstract}

Key-words: Anxiety, depression, economic stressors, mental health, stress

\section{A RECESSÃO ECONÓMICA E A SAÚDE MENTAL: ANÁLISE DA SITUAÇÃO PORTUGUESA}

RESUMO - Recentemente, alguns países europeus (e.g., Grécia, Irlanda e Portugal) sofreram uma recessão económica, principalmente devido a problemas no sistema bancário e a uma elevada dívida soberana. Stressores económicos, tais como dificuldades económicas, ameaça financeira e bem-estar financeiro podem contribuir negativamente para a saúde psicológica dos indivíduos, potenciando o aparecimento de psicopatologia. O objetivo da presente investigação foi analisar o impacto de stressores económicos (i.e., dificuldades económicas, ameaça financeira e bem-estar financeiro) em indicadores de saúde mental (stresse, ansiedade e depressão). Foram recolhidos dados de uma amostra de 729 participantes portugueses, $482(66,1 \%)$ do género feminino e 247 (33,9\%) do masculino, com uma média de idades de, aproximadamente, 37 anos $(M=36,99 ; D P=12,81)$. Foi utilizado um Modelo de Equações Estruturais para

- Centre for Spatial and Organizational Dynamics, University of Algarve, Campus de Gambelas - Building 9., 8005-139 Faro, Portugal. Telef.: (+351)961482781. E-mail: joaonrviseu@gmail.com 
examinar a relação entre as variáveis de stresse económico e saúde psicológica. Os resultados obtidos apresentaram um modelo em que as dificuldades económicas e a ameaça financeira eram preditores significativos de stresse, ansiedade e depressão, ao passo que o bem-estar financeiro se assumiu como uma variável preditora da ansiedade e depressão. Algumas implicações destes resultados são discutidas.

Palavras-chave: Ansiedade, depressão, saúde mental, stresse, stressores económicos.

Recebido em 04 de Novembro de 2014/ Aceite em 06 de Junho de 2015

The current global economic downturn, which emerged in 2007, has had a negative impact on economies all over the world (Yurtsever, 2011). Various countries (e.g., Greece, Ireland, and Portugal), have been facing problems in the banking system and vulnerabilities in the sovereign debt (Monastiriotis, 2013). In order to deal with these situations, some countries (e.g., Portugal) have implemented austerity measures (Monastiriotis, 2013).

Economic downturns generate uncertainty in populations (Cooper, 2012), especially because of decreases in: (a) job security; (b) wages; (c) social service benefits; and (d) healthcare expenditures (Keegan, Thomas, Normand, \& Portela, 2013; Marjanovic, Greenglass, Fiksenbaum, \& Bell, 2013). On the other hand, increases in: (a) debt levels; (b) investment losses; (c) unemployment, mainly youth unemployment; and (d) household costs, also contribute to an increase in threat perceptions (Boone, van Ours, Wuellrich, \& Zweimuller, 2011; Keegan et al., 2013; Mielcova, 2012).

Personal financial situations have worsened, for some to the point of exasperation (Barr, TaylorRobinson, Scott-Samuel, McKee, \& Stuckler, 2012). According to a study of Sperling, Bleich, and Reulbach (2008), the public's initial reaction to the crisis was characterized by fear, anxiety, and a generalized sense of panic. Several years into the crisis, the mood of populations about their health and the trajectory of their economies remains largely negative (Barr et al., 2012). Health-related consequences, such as substance abuse (e.g., alcohol), coronary heart problems, and suicide are common in difficult economic periods (Catalano, 1991; Ferrie, Kivimaki, Shipley, Smith, \& Virtanen, 2013; Vijayasiri, Richman, \& Rospenda, 2012).

Recent studies across the social sciences have shown that the deterioration of personal finances, which is itself exacerbated by economic downturns, is a major source psychological turmoil (Althouse, Allem, Childers, Dredze, \& Ayers, 2014; Astell-Bur

\& Feng, 2013; Catalano et al., 2011; Sargent-Cox, Butterworth, \& Anstey, 2011). In fact, studies have linked personal financial problems as a contributing factor to a wide array of negative psychosocial outcomes, such as psychological distress, mental illness (Fitch, Hamilton, Bassett, \& Davey, 2011), depression (Mirowsky \& Ross,2001), dissatisfaction with life, and dysfunctional impulsivity (Bechtel, 2012; Norvilitis, Szablicki, \& Wilson, 2003).

A set of studies that indicate the existence of an association between the aforesaid constructs (i.e., distress, anxiety, and depression) and economic hardship, financial threat, and financial wellbeing (i.e., economic stressors) is presented below.

In Catalano's (1991) review about the effects of economic insecurity in health, it was demonstrated that stress levels increase during adverse economic periods. Aspects such as unemployment, an aspect that rises in economic recessions, is also associated with distress (Catalano et al., 2011). Two researches (Butterworth, Rodgers, \& Windsor, 2009; Sargent-Cox et al., 2011) observed that anxiety and depression were significantly correlated with economic hardship. Similar results were verified by Greenglass, Marjanovic, and Fiksenbaum (2013). A recent study (Leal, Viseu, Jesus, Paixão, \& Greenglass, 2014), conducted in Portugal, presented 


\section{ECONOMIC RECESSION AND MENTAL HEALTH IN PORTUGAL}

some explanatory results about the influence of financial threat and economic hardship on the variance of stress, depression, and anxiety.

If financial satisfaction is an integral component of overall life satisfaction and well-being (Stevenson \& Wolfers, 2008), than the accumulation of stressful financial events may cause financial stress and lower financial well-being. Norvilitis et al. (2003), Diener, $\mathrm{Ng}$, Harter, and Arora (2010), and Stevenson and Wolfers (2008) demonstrated that perceived financial well-being is related to one's overall psychological well-being. Research has also shown that lack of financial well-being may cause social, physical, and emotional stress (Weisman, 2002).

In the Portuguese case, it is very important to study the psychological impact of the economic crisis. This country was the third, within Europe, to have an assistance program developed by the International Monetary Fund (IMF), European Comission (EC), and European Central Bank (ECB) (Yurtsever, 2011). However, before the execution of the abovementioned program, Portugal was already implementing austerity measures defined by the country's Government (Cabral, 2013). Cabral (2013) argued that the main consequences of the Portuguese crisis were: (a) high sovereign debt; (b) high external debt; and (c) lack of equilibrium in the balance of payments, since the volume of imports was higher than the level of exports. Wage cuts, reduction of retirement pensions, and a large increase in taxes, namely in the value-added tax (VAT), were the key financial consolidation measures introduced (Cabral, 2013). As a result, and due to the external environment of the country, it was verified, between 2007-2013, a growth in the number of companies that requested insolvency or bankruptcy (Directorate-General for Justice Policy, 2013) and a raise in unemployment taxes, between January-April of 2011 Portugal had 12.4\% unemployment rate, nevertheless that value expanded to $15.8 \%$ between January-April 2012 (Cabral, 2013). Relating to youth unemployment, it was possible to observe an enlargement of this rate by about $20 \%$ between late 2010 and January-March of 2013 (2010: 23\%; 2012: 40\%; January-March 2013: 42.1\%) (Statistics Portugal, 2013). As a consequence of this situation, there has been an increased flow of emigration in highly qualified graduates (Cairns, 2013).

The objectives of the current research were to analyze the relationship between economic stressors (i.e., economic hardship, financial threat, and financial well-being) and mental health indicators (i.e., stress, anxiety, and depression) (Figure 1). This paper aims to contribute to the current state of the art about the effects of the current economic recession in mental health, presenting the case of a country, Portugal, which was severely affected by this adverse economic environment.

To accomplish this objective, nine research hypotheses were proposed:

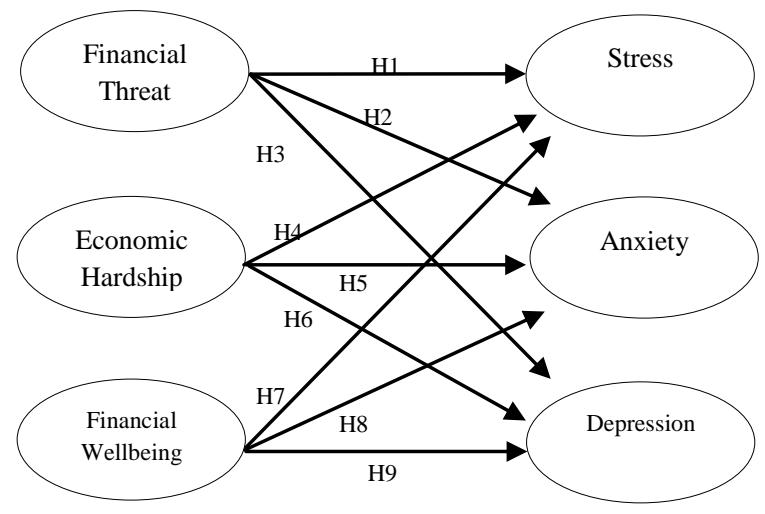

Figure 1.

Presentation of the conceptual model with the defined research hypotheses. 
To sum up, the following hypotheses were defined:

H1. Financial threat positively influences stress.

H2. Financial threat positively influences anxiety.

H3. Financial threat positively influences depression.

H4. Economic hardship positively influences stress.

H5. Economic hardship positively influences anxiety.

H6. Economic hardship positively influences depression.

H7. Financial well-being positively influences stress.

H8. Financial well-being positively influences anxiety.

H9. Financial well-being positively influences depression.

\section{METHOD}

\section{Participants}

The study's sample was composed by 729 Portuguese participants who answered a research protocol designed by Greenglass (2008). In the present research economic stressors (i.e., economic hardship, financial threat, and financial well-being) and mental health indicators (i.e., stress, anxiety, and depression) were evaluated. The respondent's mean age was, approximately, 37 years old $(M=36.77 ; S D=12.81)$. A description of the sample is presented in table 1 .

Table 1.

Sample characterization $(N=729)$

\begin{tabular}{lcc}
\hline Sample characteristics & $n$ & $\%$ \\
\hline Gender & & \\
\hline Male & 247 & 33.9 \\
Female & 482 & 66.1
\end{tabular}

Educational background

\begin{tabular}{lcc}
\hline Elementary school & 35 & 5 \\
High school & 211 & 29 \\
Bachelor's degree & 96 & 13 \\
Master's and PhD degrees & 379 & 53 \\
\hline
\end{tabular}

Note. $n$ : Number of individuals per characteristic; \%: Percentage of individuals per characteristic. 


\section{ECONOMIC RECESSION AND MENTAL HEALTH IN PORTUGAL}

\section{Material}

Economic hardship was measured by the Economic Hardship Questionnaire (EHQ) (Lempers, Clark-Lempers, \& Simons, 1989), which presented 10 items with four answer options (1-Never; 4 - Very often). In its' validation study (Lempers et al., 1989) this questionnaire presented a Cronbach's Alpha of $0.85(M=2.49 ; S D=0.65)$.

In turn, financial threat was assessed by the Financial Threat Scale (FTS) (Marjanovic et al., 2013) composed by five items organized in a five-point Likert-scale ( 1 - Not at all; 5 - Extremely Uncertain). In the validation study of FTS (Marjanovic et al., 2013) a Cronbach's Alpha value of 0.91 was obtained $(M=3.30 ; S D=0.86)$.

Financial well-being was evaluated with the Financial Well-Being Scale (FWBS) (Norvilitis et al., 2003) that included eight items with a five-point Likert-Scale (1 - Strongly Disagree; 5Strongly Agree). The Cronbach's Alpha achieved in the validation process of FWBS (Norvilitis et al., 2003) was $0.74(M=24.77 ; S D=5.92)$.

Lastly, stress, anxiety, and depression were measured by the Depression Anxiety Stress Scale 21-item version (DASS-21) (Lovibond \& Lovibond, 1995), using the adapted version for the Portuguese population of Pais-Ribeiro, Honrado, and Leal (2004). This scale was composed by 21 items, seven items for each construct (i.e, stress, anxiety, and depression), and possessed a fourpoint answer scale ( $O$ - Did not aply to me at all - Never; 3 - Applied to me very much, or most of the time - Almost Always). The Cronbach's Alpha of this scale for the constructs stress, anxiety, and depression was, respectively: (a) $0.92(M=7.17 ; S D=5.39)$; (b) $0.90(M=4.06 ; S D=4.51)$; and (c) 0.86 ( $M=4.85 ; S D=4.84$ ) (Lovibond \& Lovibond, 1995). In the adaptation study for Portugal, the Cronbach's Alpha values achieved were higher than 0.70 (Pais-Ribeiro et al., 2004).

\section{Procedures}

The questionnaire, developed by Greenglass (2008), was applied between March-June 2013, through an online survey which was distributed via an email that explained the objectives of the research and provided information about the response link. An inclusion criterion set for the questionnaires' answer was that the respondents had to be over eighteen years old. As a result, responses from participants younger than the abovementioned age were excluded from the sample. The contacted participants were integrated in a contact database created from previous researches at a Portuguese University. Furthermore, in the email sent to the participants, they were asked to forward that message to their personal contacts. In the instructions section of the questionnaire, which preceded the presentation of the instruments, a paragraph was included informing potential participants that all the obtained responses were confidential and the information provided by the respondents would only serve the purpose of this study.

\section{Data Analysis Methods}

In a first moment, an exploratory reliability analysis was conducted on the study's variables and items that compose their measurement. Some items' scale on one measure were reverted, in order that high values in all items express the same positive or negative perception on that measure. To assess the measures' reliability, the commonly indicators of scale reliability, Cronbach's Alpha and the Cronbach's Alpha if Item Deleted, were observed. The Corrected Item-Total Correlation (CITC) was computed, in order to inform about the relationships between individual items and each scale. Items with a CI-TC lower than 0.3 can be excluded from the scale, since they reveal a weak correlation with it (Betz, 2000). The items that were not eliminated as a result from the reliability analysis were considered as indicators in the structural equation model (SEM) used to test the research hypotheses (Table 2). 
SEM requires that data follows a multivariate normal distribution. There is no consensus about the departures from normality that compromise the conclusions about the quality of the model (Finney \& DiSefano, 2006). However, these authors and others (e.g., Curran, West, \& Finch, 1996) refer that the most commonly used estimation methods in SEM, the maximum likelihood (ML) and the generalized least squares (GLS) estimation methods, still produce proper results if items report skewness and kurtosis values lower than 2 and 7, respectively. Regarding our study, all items presented in table 2 fulfilled this condition. SEM was then used to examine the relationship between the economic stress variables and the psychological health variables. AMOS 20 was used to estimate and evaluate the model and the ML estimation method was applied. The analysis of the overall model fit relied on three types of measures: (a) absolute fit; (b) incremental fit; and (c) parsimonious fit (Hair, Anderson, Tatham, \& Black, 1998). The measurement model was assessed in terms of reliability and (convergent and discriminant) validity. The research hypotheses were tested by observing the sign and statistical significance of the estimated path coefficients.

\section{RESULTS}

\section{Overall model fit}

Overall model fit indicates the extent to which the chosen indicators represent the hypothesized constructs. Regarding the absolute fit evaluation, the Chi-square statistics is high and statistically significant $\left(\chi^{2}=2001.65 ; p<0.0001\right)$, failing to support a non-significant difference between the actual and the predicted models. However, since this statistics is quite sensitive to sample size and model complexity, other indices assessing the discrepancy between the actual and the predicted models should be observed (Anderson \& Gerbing, 1982). The results for these indices are summarized in table 2. The Goodness of Fit Index (GFI) and the Root Mean Square Error of Approximation (RMSEA) are 0.86 and 0.06 , respectively. The registered fit value for the RMSEA can be considered as satisfactory, however the value of the GFI (0.86) is lower than the cut-off of 0.90, which indicates a good fit according to Marôco (2014). Nonetheless, due to the proximity of these values (i.e., 0.86 and 0.90) it was decided to accept the GFI score, considering it as suggesting an acceptable fit. Incremental fit measures, which compare the model's fit compared to a null model (i.e., a model with no relations among the constructs and the indicators), ranged from 0.84 to 0.92 , suggesting a moderate to good incremental adjustment. The same finding applies to the parsimonious fit indices that assess the model's goodness of fit, but considering the number of parameters being estimated.

\section{Measurement model fit}

Before assessing the structural model (and thus make conclusions about the research hypotheses), an adequate measurement model is necessary (Anderson \& Gerbing, 1982). So, with an acceptable overall model fit, our evaluation proceeds with the analysis of the measurement model in terms of reliability and validity (Table 3). Starting with individual reliability, we can see that all standardized factor loadings are higher than the threshold value of 0.5 and are significant at the 0.01 level $(p<0.0001)$. 
Table 2.

Overall model fit indices

\begin{tabular}{|c|c|c|}
\hline Goodness of fit criterion & Observed value & Comment \\
\hline \multicolumn{3}{|l|}{ Absolute fit measures } \\
\hline GFI & 0.86 & Acceptable fit \\
\hline RMSEA & 0.06 & Satisfactory fit \\
\hline \multicolumn{3}{|l|}{ Incremental fit measures } \\
\hline AGFI & 0.84 & Satisfactory fit \\
\hline CFI & 0.92 & Good fit \\
\hline NFI & 0.89 & Satisfactory fit \\
\hline TLI & 0.91 & Good fit \\
\hline IFI & 0.92 & Good fit \\
\hline \multicolumn{3}{|l|}{ Parsimonious for measures } \\
\hline PCFI & 0.84 & Good fit \\
\hline PNFI & 0.81 & Good fit \\
\hline$\chi^{2} / \mathrm{df}$ & 3.46 & Satisfactory fit \\
\hline \multicolumn{3}{|c|}{$\begin{array}{l}\text { Note. GFI: Goodness of Fit Index; RMSEA: Root Mean Square Error of } \\
\text { Approximation; AGFI: Adjusted Goodness of Fit Index; CFI: Comparative Fit Index; } \\
\text { NFI: Normed Fit Index; TLI: Tucker-Lewis Index; IFI: Incremental Fit Index; PCFI: } \\
\text { Parsimony Comparative Fit Index; PNFI: Parsimony Normed Fit Index; } \chi^{2} \text { : Chi-square } \\
\text { test; df: Degrees of freedom. }\end{array}$} \\
\hline
\end{tabular}

These results show that all indicators are positively and significantly related to their specified constructs. Construct reliability is also very good since the Cronbach's Alpha and the composite reliability (CR) coefficients exceed 0.8 (Kline, 1998).

Table 3.

Measurement model fit indices

\begin{tabular}{lccc}
\hline Latent variables and indicators & Std. loadings $^{*}$ & CR & AVE \\
\hline Financial Threat & & 0.89 & 0.62 \\
FT1 - How uncertain do you feel? & 0.83 & & \\
FT2-How much do you feel at risk? & 0.92 & & \\
FT3 - How much do you feel threatened? & 0.91 & & \\
FT4-How much do you worry about it? & 0.70 & & \\
FT5 - How much doyou think about it? & 0.65 & & 0.53 \\
\hline Economic Hardship & & & \\
EH1 -Cut back on social activities and entertainment expenses. & 0.74 & & \\
EH2-Postponemajor household purchases. & 0.72 & & \\
EH3-Postpone clothing purchases. & 0.74 & & \\
EH4-Change transportation patterns to save money. & 0.59 & & \\
EH5-Change food shopping or eating habits to save money. & 0.71 & & \\
EH7-Reduce household utility use. & 0.77 & & \\
\hline
\end{tabular}




\begin{tabular}{|c|c|c|c|}
\hline (Cont.) & & & \\
\hline Financial Well-Being & & 0.82 & 0.53 \\
\hline FWB1 - Iam uncomfortable with the amount of debt I am in. & 0.89 & & \\
\hline FWB2 - I worry about repaying my loans. & 0.86 & & \\
\hline FWB3 -I worry about repaying my credit cards. & 0.68 & & \\
\hline FWB5 - Ithink a lot about the debt I am in. & 0.84 & & \\
\hline Stress & & 0.93 & 0.64 \\
\hline S1 - I found it hard to wind down. & 0.75 & & \\
\hline S2-I tended to over-react to situations. & 0.74 & & \\
\hline S3 - I felt that I was using a lot of nervous energy. & 0.76 & & \\
\hline S4-I found myself getting agitated. & 0.81 & & \\
\hline S5-I found it difficult to relax. & 0.83 & & \\
\hline $\begin{array}{l}\text { S6 - I was intolerant of anything that kept me from getting on with what I } \\
\text { was doing. }\end{array}$ & 0.74 & & \\
\hline S7-I felt that I was rather touchy. & 0.83 & & \\
\hline Anxiety & & 0.91 & 0.60 \\
\hline A1 - I was aware of dryness of my mouth. & 0.60 & & \\
\hline A2-I experienced breathing difficulty. & 0.66 & & \\
\hline A3-Iexperienced trembling. & 0.70 & & \\
\hline $\begin{array}{l}\text { A4 - I was worried about situations in which I might panic and make a } \\
\text { fool of myself. }\end{array}$ & 0.76 & & \\
\hline A5-I felt I was close to panic. & 0.82 & & \\
\hline $\begin{array}{l}\text { A6 - I was aware of the action of my heart in the absence of physical } \\
\text { exertion. }\end{array}$ & 0.68 & & \\
\hline A7-Ifelt scared without any good reason. & 0.79 & & \\
\hline Depression & & 0.92 & 0.63 \\
\hline D1 - I couldn't seem to experience any positive feeling at all. & 0.73 & & \\
\hline D2-I found it difficult to work up the initiative to do things. & 0.67 & & \\
\hline D3 - I felt that Ihad nothing to look forward to. & 0.77 & & \\
\hline D4 -I felt down-hearted and blue. & 0.82 & & \\
\hline D5 - I was unable to become enthusiastic about anything. & 0.82 & & \\
\hline D6-I felt I wasn't worth much as a person. & 0.76 & & \\
\hline D7 - I felt that life was meaningless. & 0.66 & & \\
\hline
\end{tabular}

Note. Std. loadings: Standardized factor loadings; CR: Composite reliability; AVE: Average Variance Extracted; ${ }^{*}$ For all standardized loadings: $p=0.000$.

The average variance extracted (AVE) is a commonly used measure of convergent validity showing the degree to which items' behaviour is explained by the construct. One construct is considered to have sufficient convergent validity when its AVE is higher than 0.5 (Fornell \& Lacker, 1981). In our study, all six constructs surpass this threshold value. Lastly, discriminant 


\section{ECONOMIC RECESSION AND MENTAL HEALTH IN PORTUGAL}

validity evaluates the extent to which the indicators of one construct are not too related with other constructs. A commonly used way to detect discriminant validity is to verify if the AVE value for one construct is higher than any squared correlation between this construct and the remaining. Table 4 shows that discriminant validity is upheld for our measurement model regarding both the economic stress variables (variables 1 to 3 ) and the psychological health variables (variables 4 to 6).

Table 4.

Discriminant validity assessment ${ }^{*}$

\begin{tabular}{l|c|c|c|c|c|c}
\hline Latent variables & 1. & 2. & 3. & 4. & 5. & 6. \\
\hline 1. Financial Threat & $\mathbf{0 . 6 9}$ & & & & & \\
2. Economic Hardship & 0.28 & $\mathbf{0 . 5 3}$ & & & & \\
3. Financial Well Being & 0.14 & 0.13 & $\mathbf{0 . 5 3}$ & & & \\
4. Stress & --- & --- & --- & $\mathbf{0 . 6 4}$ & & \\
5. Anxiety & --- & --- & --- & 0.64 & $\mathbf{0 . 6 0}$ & \\
6. Depression & --- & --- & --- & 0.64 & 0.54 & $\mathbf{0 . 6 3}$ \\
\hline
\end{tabular}

Note. Bolded values are the AVE's. The remaining values are the squared correlations.

\section{Structural model parameters}

Figure 2 shows the standardized path estimates on the model itself. Results show that all estimated coefficients have the expected positive signal. With the exception of the path relationship between stress and financial well-being, all paths proposed in the conceptual model are statistically significant $(p<0.01)$. So, excluding hypothesis 7 , all the research hypotheses are not rejected, supporting causal relationships among the economic stress variables and the psychological health variables. The squared multiple correlations (SMC) for the endogenous constructs (i.e., stress, anxiety, and depression) are within the ellipses. The low values for the SMCs are not surprising, because it is expected that other constructs, not considered in this study, are also important predictors of the psychological health variables. Since the regression weights are standardized, we can conclude that the stronger relationships are those involving economic hardship and stress (path estimate $=0.26$ ), on one hand, and financial threat and stress (path estimate $=0.24$ ), on the other hand. The weaker relationships were found between financial well-being and depression (path estimate $=0.11$ ), and economic hardship and depression (path estimate $=0.18$ ).

Figure 2.

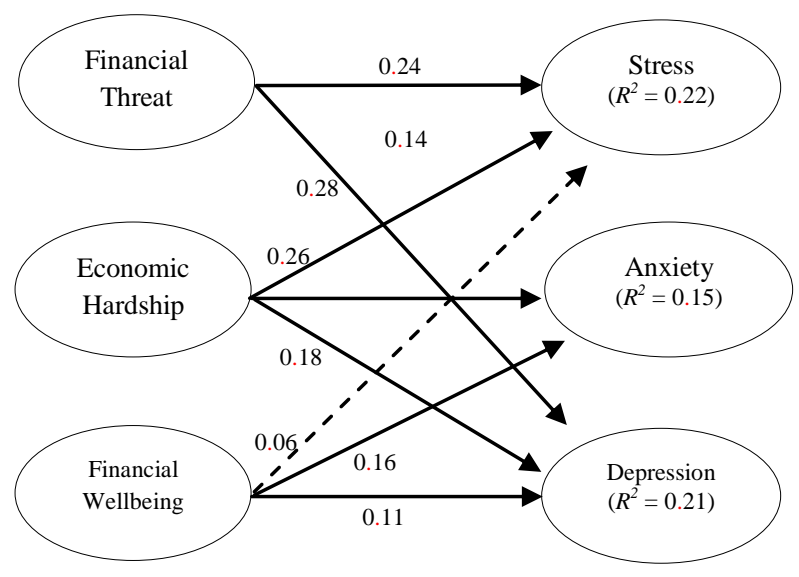

Structural model results. The solid lines indicate paths statistically significant $(p<0.01)$, while the dashed line indicates a non-significant path $(p>0.05)$. 


\section{DISCUSSION}

In sum, our study demonstrated that during phases of economic turmoil aspects like financial threat and economic hardship (i.e., economic stressors) have a significant impact on stress, anxiety, and depression (i.e., mental health indicators). The obtained results are congruent with the existing literature. The reviews of Catalano (1991) and Catalano et al. (2011) verified that symptoms of stress, anxiety, and depression increase in periods of economic recession. Past researches performed by Butterworth et al. (2009), Greenglass et al. (2013), and Sargent-Cox et al. (2011) demonstrated that anxiety and depression are highly correlated with adverse financial cycles. Lastly, Leal et al. (2014) also observed the existence of a significant impact of economic stressors on mental health indicators. However, although financial well-being has been significantly associated with anxiety and depression, it was not a significant predictor of stress. This is partially confirmed by other studies (e.g., Weisman, 2002; Norvilitis et al. 2003), which have demonstrated that perceived financial well-being is related to one's overall psychological well-being.

In other words, our data confirms that, overall, the economic recession influences individual's psychological health, since economic stressors (i.e., economic hardship and financial threat) are significant predictors of mental health indicators (i.e., stress, anxiety, and depression). Therefore, the present research contributes to the current state of the art about the psychological impact of the economic recession, since eight of the nine hypotheses created were confirmed, and the only hypothesis that was not confirmed, given that the statistical results were not significant, pointed in the same direction, the existence of an influence of economic stressors on subject's mental health.

Future researches performed about the relationship established between economic stressors and mental health indicators should use other methodological designs (e.g., longitudinal designs), because that will allow comparisons between the aforementioned aspects in distinct economic periods (e.g., economic recession vs. economic growth). Furthermore, the sampling criteria ought to be more accurate, including subjects that belong to different social and economic backgrounds. Another interesting proposal is try to understand the reason why financial well-being does not have a significant impact on stress. Ultimately, it would be useful to realize similar studies in other European countries affected by financial crises (e.g., Cyprus, Greece, Ireland, and Spain) and compare the obtained results.

\section{REFERENCES}

Althouse, B., Allem, J., Childers, M., Dredze, M., \& Ayers, J. (2014). Population health concerns during the United States' great recession. American Journal of Preventive Medicine, 46, 166-17. doi: 10.1016/j.amepre.2013.10.008

Anderson, J., \& D. Gerbing (1982). Some methods of respecifying measurement models to obtain unidimensional construct measurement. Journal of Marketing Research, 19, 453-460. doi: $10.2307 / 3151719$

Astell-Burt, T., \& Feng, X. (2013). Health and the 2008 economic recession: Evidence from United Kingdom. Plos One, 8, 1-9. doi: 10.1371/journal.pone.0056674

Barr, B., Taylor-Robinson, D., Scott-Samuel, A., McKee, M., \& Stuckler, D. (2012). Suicides associated with the 2008-10 economic recession in England: Time trend analysis. British Medical Journal, 345(7873), 1-7. doi: 10.1136/bmj.e5142

Bechtel, G. G. (2012). The societal impact of economic anxiety. Journal of Data Science, 10, 693710. 


\section{ECONOMIC RECESSION AND MENTAL HEALTH IN PORTUGAL}

Betz N. (2000). Test construction. In F. Leong and J. Austin (Eds.). The psychology research handbook: A guide for graduate students and research assistants (pp. 239-250). Thousand Oaks, CA: Sage Publications.

Boone, J., van Ours, J., Wuellrich, J., \& Zweimuller, J. (2011). Recessions are bad for workplace safety. Journal of Health Economics, 30, 764-773. doi: 10.2139/ssrn.1816292

Butterworth, P., Rodgers, B., \& Windsor, T. (2009). Financial hardship, socio-economic position and depression: Results from the PATH Through Life Survey. Social Science \& Medicine, 69, 229-237. doi: 10.1016/j.socsimed.2009.05.008

Cabral, R. (2013). The euro crisis and Portugal's dilemma. Panoeconomicus, 4, 391-404. doi: 10.2298/PAN1004391K

Cairns, D. (2013). Youth, precarity and the future: Undergraduate housing transitions in Portugal during the economic crisis. Sociologia, Problemas e Práticas, 66, 9-25.

Catalano, R. (1991). The health effects of economic insecurity. American Journal of Public Health, 81, 1148-1152. doi: 10.2105/AJPH.81.9.1148

Catalano, R., Goldman-Mellor, S., Saxton, K., Margerison-Zilko, C., Subbaraman, LeWinn, K., \& Anderson, E. (2011). The health effects of economic decline. Annual Review of Public Health, 32, 431-450. doi: 10.1146/annurev-publhealth 031210-101146

Cooper, C. (2012). Stress in turbulent economic times. Stress and Health, 28, 177-178. doi: 10.1002/smi.2442

Curran, P. J., West, S. G., \& Finch, J. F. (1996). The robustness of test statistics to nonnormality and specification error in confirmatory factor analysis. Psychological Methods, 1, 16-29. doi: 10.1037/1082-989X.1.1.16

Diener, E., Ng, W., Harter, J., \& Arora, R. (2010). Wealth and happiness across the world: material prosperity predicts life evaluation, whereas psychosocial prosperity predicts positive feeling. Journal of Personality and Social Psychology, 99, 52-61. doi: 10.1037/a0018066

Directorate-General for Justice Policy (2013). Destaque estatístico trimestral [Quarterly statistical feature]. Boletim de Informação Estatística Trimestral, 9, 1-7.

Ferrie, J., Kivimaki, M., Shipley, M., Smith, G., \& Virtanen, M. (2013). Job insecurity and incident coronary heart disease: The Whitehall II prospective cohort study. Atherosclerosis, 227, 178181. doi: 10.1016/j.atherosclerosis.2012.12.027

Finney, S. J.,\&DiStefano, C. (2006). Nonnormal and categorical data in structural equation models. In G.R. Hancock and R.O. Mueller (Eds.). A second course in structural equation modeling (pp. 269 - 314). Greenwich, CT: Information Age.

Fitch, C., Hamilton, S., Bassett, P., \& Davey, R. (2011). The relationship between personal debt and mental health: A systematic review. Mental Health Review Journal, 16, 153-166. doi: 10.1108/13619321111202313

Fornell, C., \& Larcker, D. F. (1981). Evaluating structural equation models with unobservable variables and measurement error. Journal of Marketing Research, 18, 39-50. doi: $10.2307 / 3151312$

Greenglass, E. (2008). Economic Downturn Study: Survey of daily Events. Unpublished questionnaire.

Greenglass, E., Marjanovic, Z., \& Fiksenbaum, L. (2013). The impact of the recession and its aftermath on individual health and well-being. In A. Antoniou \& C. Cooper (Eds.), The psychology of the recession on the workplace (pp. 42-58). Cheltenham: Edward Elgar Publishing.

Hair, J.F., Anderson, R.E., Tatham, R.L. \&Black, W. C. (1998). Multivariate data analysis with readings (5th ed.). Englewood Cliffs, NJ: Prentice-Hall International. 
Keegan, C., Thomas, S., Normand, C., \& Portela, C. (2013). Measuring recession severity and its impact on health expenditure. International Journal of Health Care Finance and Economics, 13, 139-155. doi: 10.1007/s10754-012-9121-2

Kline, R. B. (1998). Software Review: Software Programs for Structural Equation Modeling: Amos, EQS, and LISREL. Journal of Psychoeducational Assessment, 16, 343-364. doi: 10.1177/073428299801600407

Leal, R., Viseu, J., Jesus, S. N., Paixão, O., \& Greenglass, E. (2014). Economic stressors and symptoms of psychological distress: Data from a Portuguese sample. In K. Kaniasty, K. Moore, S. Howard, \& P. Buchwald (Eds.), Stress and Anxiety: Applications to Social and Environmental Threats, Psychological Well-Being, Occupational Challenges, and Developmental Psychology (pp. 17-23). Berlin: Logos Verlag.

Lempers, J., Clark-Lempers, D., \& Simons, R. (1989). Economic hardship, parenting, and distress in adolescence. Child Development, 60, 25-39. doi: 10.1111/j.1467-8624.1989.tb02692.x

Lovibond, S., \& Lovibond, P. (1995). Manual for the Depression Anxiety Stress Scales. (2 ${ }^{\text {nd }}$ Ed.). Sydney: Psychology Foundation.

Marjanovic, Z., Greenglass, E., Fiksenbaum, L., \& Bell, C. (2013). Psychometric evaluation of the Financial Threat Scale (FTS) in the context of the great recession. Journal of Economic Psychology, 36, 1-10. doi: 10.1016/j.joep.2013.02.005

Marôco, J. (2014). Análise de equações estruturais: Fundamentos teóricos, software \& aplicações. (2. ${ }^{a}$ ed.). Pêro Pinheiro: ReportNumber.

Mielcova, E. (2012). Impact of the financial crisis on European householders. In D. Stavarek \& P. Vodová (Eds.), Proceedings of the 13th International Conference of Finance and Banking (pp. 416-426). Ostrava, Czech Republic: Silesian University, School of Business Administration.

Mirowsky, J., \& Ross, C. E. (2001). Age and the effect of economic hardship on depression. Journal of Health and Social Behavior, 42, 132-150. doi: 10.2307/3090174

Monastiriotis, V. (2013). Austerity measures in crisis countries - results and impacts on mid-term development. Intereconomics, 1, 4-32. doi: 10.1007/s10272-013-0441-3

Norvilitis, J. M., Szablicki, P. B., \& Wilson, S. D. (2003). Factors influencing levels of credit card debt in college students. Journal of Applied Social Psychology, 33, 935-947. doi: 10.1111/j.1559-1816.2003.tb01932.x

Pais-Ribeiro, Honrado, A., \& Leal, I. (2004). Contribuição para o estudo da adaptação portuguesa das escalas de ansiedade, depressão e stress (EADS) de 21 itens de Lovibond e Lovibond. Psicologia, Saúde \& Doenças, 5, 229-239.

Sargent-Cox, K., Butterworth, P., \& Anstey, K. (2011). The global financial crisis and psychological health in a sample of Australian older adults: a longitudinal study. Social Science \& Medicine, 73, 1105-1112. doi: 10.1016/j.socsimed.2011.06.063

Sperling, W., Bleich, S., \& Reulbach, U. (2008). Black Monday on stock markets throughout the world - A new phenomenon of collective panic disorder? A psychiatric approach. Medical Hypotheses, 71, 972-974. doi: 10.1016/j.mehy.2008.04.028

Statistics Portugal (2013). Estatísticas de emprego: $1 .^{\circ}$ trimestre 2013 [Employment Statistics: $1^{\text {st }}$ quarter 2013]. Statistics Portugal, 1, 1-8.

Stevenson, B., \& Wolfers, J. (2008). Economic growth and subjective well-being: Reassessing the easterlin paraxodox. Massachusetts: National Bureau of Economic Research.

Vijayasiri, G., Richman, J., \& Rospenda, K. (2012). The great recession, somatic symptomatology and alcohol use and abuse. Addictive Behaviors, 37, 1019-1024. doi: 10.1016/j.addbeh.2012.04.007 


\section{ECONOMIC RECESSION AND MENTAL HEALTH IN PORTUGAL}

Weisman, R. (2002). Personal financial stress, depression and workplace performance. Financial stress and workplace performance: Developing employer-credit union partnerships (pp. 51-66). Madison, WS: Filene ResearchInstitute.

Yurtsever, S. (2011). Investigating the recovery strategies of European Union from the global financial crisis. Procedia Social and Behavioral Sciences, 24, 687-695. doi: 10.1016/j.sbspro.2011.09.132 